\title{
Antigenic analysis of iron-regulated proteins in Pasteurella haemolytica $A$ and $T$ biotypes by immunoblotting reveals biotype-specific epitopes
}

\author{
John E. Murray, * Richard C. Davies, F. Alexander lainson, Christina F. Wilson and \\ WILliAM DONACHIE
}

Moredun Research Institute, 408 Gilmerton Road, Edinburgh EHI7 7JH, UK

(Received 25 October 1991; accepted 13 November 1991)

\begin{abstract}
The antigenic relationships of the iron-regulated proteins (IRPs) in Pasteurella haemolytica A and T biotype strains were examined by SDS-PAGE and immunoblotting. P. haemolytica cells of the A biotype, grown under conditions of iron-limitation, expressed two IRPs, of 35 and $70 \mathrm{kDa}$. All T biotype strains expressed IRPs with slightly different molecular masses of 37 and $78 \mathrm{kDa}$. Immunoblotting of all $16 P$. haemolytica serotypes was carried out using a panel of polyclonal and monoclonal antibodies raised against serotype A2 antigens. Polyclonal antibodies revealed inter-serotype cross-reactivity towards the 35 and $70 \mathrm{kDa}$ IRPs within the A biotype but no cross-reactivity against a $T$ biotype protein in the $78 \mathrm{kDa}$ region. Monoclonal antibody against the $35 \mathrm{kDa}$ antigen reacted only with the A biotype $35 \mathrm{kDa}$ IRP. Identical profiles were obtained for 10 field isolates of serotype A2, further emphasizing the antigen conservation within the A biotype. These findings reinforce the view that the $A$ and T biotypes of $P$. haemolytica should be considered as separate species and suggest that IRPs from single A and T biotype strains incorporated into a vaccine might provide cross-protection against all $P$. haemolytica serotypable strains. Similar studies on the IRPs of $\mathbf{1 0}$ untypable strains revealed some of these to have different antigenic reactivities from those observed within the $A$ and $T$ biotypes.
\end{abstract}

\section{Introduction}

Pasteurellosis, caused by Pasteurella haemolytica, is a serious, often fatal respiratory disease in sheep, cattle and goats (Gilmour, 1980). Predisposing factors are implicated in the disease (Harris, 1974; Davies et al., 1980), but the ultimate cause of death is considered to be pneumonia caused by $P$. haemolytica.

Isolates of $P$. haemolytica fall into two distinct biotypes (A and $\mathrm{T}$ ) depending on their morphological and biochemical characteristics. Sixteen serotypes based upon capsular antigen diversity can be identified by an indirect haemagglutination test (IHA). Serotypes 3, 4, 10 and 15 belong to the $\mathrm{T}$ biotype, and $1,2,5,6,7,8,9,11$, $12,13,14$ and 16 are of the A biotype (Biberstein et al., 1960 ; Fraser et al., 1982; Fodor et al., 1988). In addition, approximately $12 \%$ of all isolates are untypable in the IHA typing system.

* Author for correspondence. Tel. (031) 664 3262; fax (031) 6648001.

Abbreviations: dp, 2,2'-dipyridyl; IHA, indirect haemagglutination; IRP, iron-regulated protein; NB, nutrient broth; SPF, specificpathogen-free.
Proper management and vaccination are the accepted means of control for the disease. Vaccines containing cell extracts of serotypes A1, A6 and A9 conferred a considerable degree of protection on specific-pathogenfree (SPF) lambs against homologous, but not heterologous challenge (Gilmour et al., 1983). However, protection against the A2 serotype, which is the predominant ovine isolate from field cases, has proven more difficult to demonstrate with cell extract vaccines.

Solid immunity against the A2 serotype was demonstrated when SPF lambs recovered from experimental pasteurellosis caused by serotype A2 were subsequently challenged (Donachie et al., 1986). Sera from these sheep contained antibodies directed against iron-regulated proteins (IRPs). These proteins were demonstrated in bacteria collected from host tissue and body fluids, and in bacteria grown in vitro under iron-depleted conditions (Donachie \& Gilmour, 1988). Moreover, IRPs were absent or only weakly expressed in cells grown in ironreplete medium. Recently, antibodies to these antigens presented on 'in vitro' grown cells have been shown to significantly enhance protection against $A 2$ challenge in the SPF lamb experimental system (Gilmour et al., 1991). Predominant IRPs of $P$. haemolytica A2 at 
apparent molecular masses of 100,70 and $35 \mathrm{kDa}$ have been identified using SDS-PAGE (Donachie \& Gilmour, 1988; Lainson et al. 1991).

The presence of antibodies specific for IRPs in the serum of immune animals recovered from infection and enhancement of vaccine efficacy by these proteins implicates them as protective antigens. As $P$. haemolytica contains 16 serotypes, shared antigenic epitopes among IRPs could be significant in possible heterologous immunity to infection.

This paper reports the cross-reactivity of antibodies against two of these iron-regulated proteins and discusses the relevance of cross-protection in vaccine development.

\section{Methods}

Bacterial strains and growth conditions. All strains used for the purpose of this comparative study were field isolates obtained from cases of ovine and bovine pasteurellosis and maintained at Moredun Research Institute as reference strains stored at $-70^{\circ} \mathrm{C}$. The details are shown in Table 1. Bacteria were subcultured and identified by the IHA test (Biberstein et al., 1960). When required, $10 \mathrm{ml}$ seed cultures were initiated in nutrient broth (NB, Gibco No. 2) and $6 \mathrm{~h}$ later, inoculated into 11 flasks of iron-depleted media obtained by the addition of $2,2^{\prime}$-dipyridyl (dp, $150 \mu \mathrm{M}$, Sigma). Cells were grown at $37^{\circ} \mathrm{C}$ for $18 \mathrm{~h}$ with shaking, then harvested by centrifugation and washed twice in PBS (0.01 M-sodium phosphate, $0.15 \mathrm{M}-\mathrm{NaCl}$, pH 7.4). Bacterial suspensions were adjusted to give protein concentrations of $2 \mathrm{mg} \mathrm{ml}^{-1}$ as determined by the Pierce BCA Protein Assay Reagent.

Preparation of bacterial envelopes. Bacterial envelopes were prepared as described by Donachie \& Gilmour (1988). Briefly, washed cells were sonicated in an MSE sonicator ( 150 watt, MK2) for three $30 \mathrm{~s}$ pulses at maximum power with intermittent cooling. The sonicate was then centrifuged at $4000 \mathrm{~g}$ and the supernatant fluid centrifuged at $30000 \mathrm{~g}$ for $1 \mathrm{~h}$ to pellet envelopes. Envelopes were resuspended in $0.1 \mathrm{M}$ Tris/ $/ \mathrm{HCl}, \mathrm{pH} 7 \cdot 4$.

SDS-PAGE and immunoblotting. $P$. haemolytica proteins were separated by SDS-PAGE, using a modification of the method described by Laemmli (1970). A discontinuous system comprising resolving and stacking gels of 10 and $4 \%(\mathrm{w} / \mathrm{v})$ acrylamide, respectively, was used. Prior to electrophoresis, bacterial preparations were boiled for $5 \mathrm{~min}$ in a $50 \%(\mathrm{v} / \mathrm{v})$ solution of a sample buffer containing $4 \%(\mathrm{w} / \mathrm{v})$ SDS and $8 \%(\mathrm{v} / \mathrm{v})$ mercaptoethanol. Separated proteins were stained with Coomassie blue R250 (Sigma).

Proteins were electrophoretically transferred to Immobilon PVDF Transfer Membrane (Millipore) by the method of Sharp \& Herring (1983). The membrane was blocked with $50 \%(\mathrm{v} / \mathrm{v})$ horse serum in Blot Wash Buffer (BWB) comprising $0.5 \mathrm{M}-\mathrm{NaCl}, 0.01 \mathrm{M}$-EDTA and $0.5 \%$ (v/v) Tween 20 in PBS, for $1 \mathrm{~h}$ at $37^{\circ} \mathrm{C}$. After three 5 min washes in BWB, the membrane was incubated at $37^{\circ} \mathrm{C}$ for $1 \mathrm{~h}$ with either hybridoma supernatant containing monoclonal antibody or specific lamb antisera at a 1:50 dilution in BWB followed by three $5 \mathrm{~min}$ washes in BWB. Bound antibody was then detected by incubation with horseradish-peroxidase-conjugated anti-mouse or sheep IgG (SAPU, Law Hospital, Carluke) for $1 \mathrm{~h}$ at $37^{\circ} \mathrm{C}$. The membrane was washed as described above, rinsed with distilled water and conjugate detected by the precipitation of the oxidized diaminobenzidine, $1 \mathrm{mg} \mathrm{ml}^{-1}$ in $0.1 \mathrm{M}$ Tris $/ \mathrm{HCl}, \mathrm{pH} 7.4$ (Sigma). The reaction was stopped by rinsing in tap water.
Table 1. P. haemolytica strains used for cross-reactivity studies

\begin{tabular}{lcl}
\hline Strain & Serotype & Source \\
\hline D0652 & A1 & Ovine \\
A713 & A2 & Ovine \\
A635 & T3 & Ovine \\
D0693 & T4 & Ovine \\
R341B & A5 & Ovine \\
D0135 & A6 & Ovine \\
D0800 & A7 & Ovine \\
D0200 & A8 & Ovine \\
D0775 & A9 & Ovine \\
D0770 & T10 & Ovine \\
B561 & A11 & Ovine \\
D0132 & A12 & Ovine \\
D0804 & A13 & Ovine \\
N513 & A14 & Ovine \\
D0685 & T15 & Ovine \\
N236 & A16 & Ovine \\
A713 & A2 & Ovine \\
Y578 & A2 & Ovine \\
A609 & A2 & Ovine \\
E0200 & A2 & Ovine \\
E674 & A2 & Ovine \\
T884 & A2 & Ovine \\
E0284 & A2 & Ovine \\
Y510 & A2 & Ovine \\
D1036 & A2 & Ovine \\
A461 & A2 & Bovine \\
D0203 & A2 & Bovine \\
B0131 & Untypable & Ovine \\
P704C & Untypable & Bovine \\
T1291B & Untypable & Ovine \\
T1255A & Untypable & Ovine \\
T1262A & Untypable & Ovine \\
S622G & Untypable & Ovine \\
S622K & Untypable & Ovine \\
T12910 & Untypable & Ovine \\
\hline \hline & & \\
& & \\
\hline
\end{tabular}

Monoclonal antibody. A monoclonal antibody specific for a $35 \mathrm{kDa}$ IRP in P. haemolytica, described by Lainson et al. (1991), was used in immunoblotting.

Antiserum. Antisera from SPF lambs recovered from an experimental A2 serotype infection (Donachie et al., 1986) were pooled and used in immunoblotting to compare the cross-reactivity of $P$. haemolytica proteins.

Antibodies to the $70 \mathrm{kDa}$ A2 serotype IRP were raised in SPF lambs by immunization with the $70 \mathrm{kDa}$ band excised from polyacrylamide gels after SDS-PAGE separation of envelopes. The bands were macerated in $0.1 \mathrm{M} \mathrm{Tris} / \mathrm{HCl}, \mathrm{pH} \mathrm{7.4,} \mathrm{and} \mathrm{Alhydrogel} \mathrm{(Superfos)} \mathrm{added}$ to a final concentration of $0.3 \%(w / v)$. Each excised strip containing approximately $100 \mu \mathrm{g}$ protein was homogenized in Alhydrogel. SPF lambs were vaccinated subcutaneously at weekly intervals with $100 \mu \mathrm{g}$ protein.

Polyclonal antiserum to the $35 \mathrm{kDa}$ A2 serotype IRP was raised in sheep following two subcutaneous injections of purified protein $(100 \mu \mathrm{g}$ per dose) obtained by affinity chromatography. Briefly, monoclonal anti-35 kDa antibody was coupled to a standard Sepharose 4B column (Pharmacia) and a sonicated lysate of iron-depleted $P$. haemolytica A2 cells in $0.5 \mathrm{M}-\mathrm{NaCl}$ was passed through the column. Bound antigen was eluted with $0 \cdot 1 \mathrm{M}$-glycine $/ \mathrm{HCl}, \mathrm{pH} 2 \cdot 3$. 


\section{Results}

Fig. 1 shows the SDS-PAGE-separated whole-cell lysates of $P$. haemolytica serotypes A2 and T3 grown in iron-depleted and iron-replete media. Two A2 serotype IRPs having molecular masses of 35 and $70 \mathrm{kDa}$ are less prominent in cells grown in iron-replete medium but are prominent bands in cells grown in iron-depleted medium. Similarly, two T3 serotype IRPs of 37 and $78 \mathrm{kDa}$ are preferentially expressed in cells grown under conditions of iron limitation. The profiles of $\mathrm{A}$ and $\mathrm{T}$ biotypes show distinct differences, which are most obvious in the $20-50 \mathrm{kDa}$ region. The lower of the two T biotype IRPs is slightly displaced from the A biotype $35 \mathrm{kDa}$ IRP and is seen at $37 \mathrm{kDa}$. Additionally, the higher molecular mass $T$ biotype IRP is evident at $78 \mathrm{kDa}$ compared to $70 \mathrm{kDa}$ in the $\mathrm{A}$ biotype. Coomassie-blue-stained profiles of the $\mathrm{A}$ and $\mathrm{T}$ biotype envelopes indicate that the 70 and $78 \mathrm{kDa}$ proteins are located in the membranes while the $35 \mathrm{kDa}$ IRP is not (unpublished observations).

Immunoblot analysis was performed to determine whether antibodies raised in sheep against experimental $P$. haemolytica A2 infection exhibited cross-reactivity with other serotypes. Immunoblots of lysates from irondepleted and iron-replete cells of serotypes 1-4 were reacted with an A2 convalescent serum pool (Fig. 2). Much cross-reactivity is exhibited and antibodies specific for the lower of the two IRPs ( 35 and $37 \mathrm{kDa}$ ) are observed in both biotypes. No cross-reactivity is evident against a $70 \mathrm{kDa}$ protein in the T serotypes and there is no reaction with the $78 \mathrm{kDa}$ IRP. Furthermore, polyclonal antiserum raised in lambs against the $\mathrm{A} 270 \mathrm{kDa}$ protein excised from polyacrylamide gels reacts with a complementary protein present in envelopes of the $\mathrm{A}$ biotype, but not the $\mathrm{T}$ biotype (Fig. 3). A band at $66 \mathrm{kDa}$, again only in the A biotype, is also recognized by this antiserum pool.

When immunoblots of iron-regulated $\mathrm{A}$ and $\mathrm{T}$ cell lysates were probed with polyclonal anti- $35 \mathrm{kDa}$ antiserum, reaction was observed with a single protein (Fig. $4 a$ ). Antibody reactivity towards the T biotype strains was with the $37 \mathrm{kDa}$ antigen. Although antibody crossreactivity with the $\mathrm{T}$ biotype protein was easily discernible, the intensity was reduced when compared to A biotype reactions.

A murine monoclonal antibody against the $35 \mathrm{kDa}$ iron-regulated protein exhibited cross-reactivity with all the A biotype strains (Fig. $4 b$ ). No reaction at $35 \mathrm{kDa}$ was observed with the $T$ serotypes. However, some contained a weakly reacting band of $<29 \mathrm{kDa}$ (Fig. $4 b$, lane 4T).

The reactivity of specific antibody to 70 and $35 \mathrm{kDa}$ antigens with ten $\mathrm{A} 2$ field isolates revealed identical

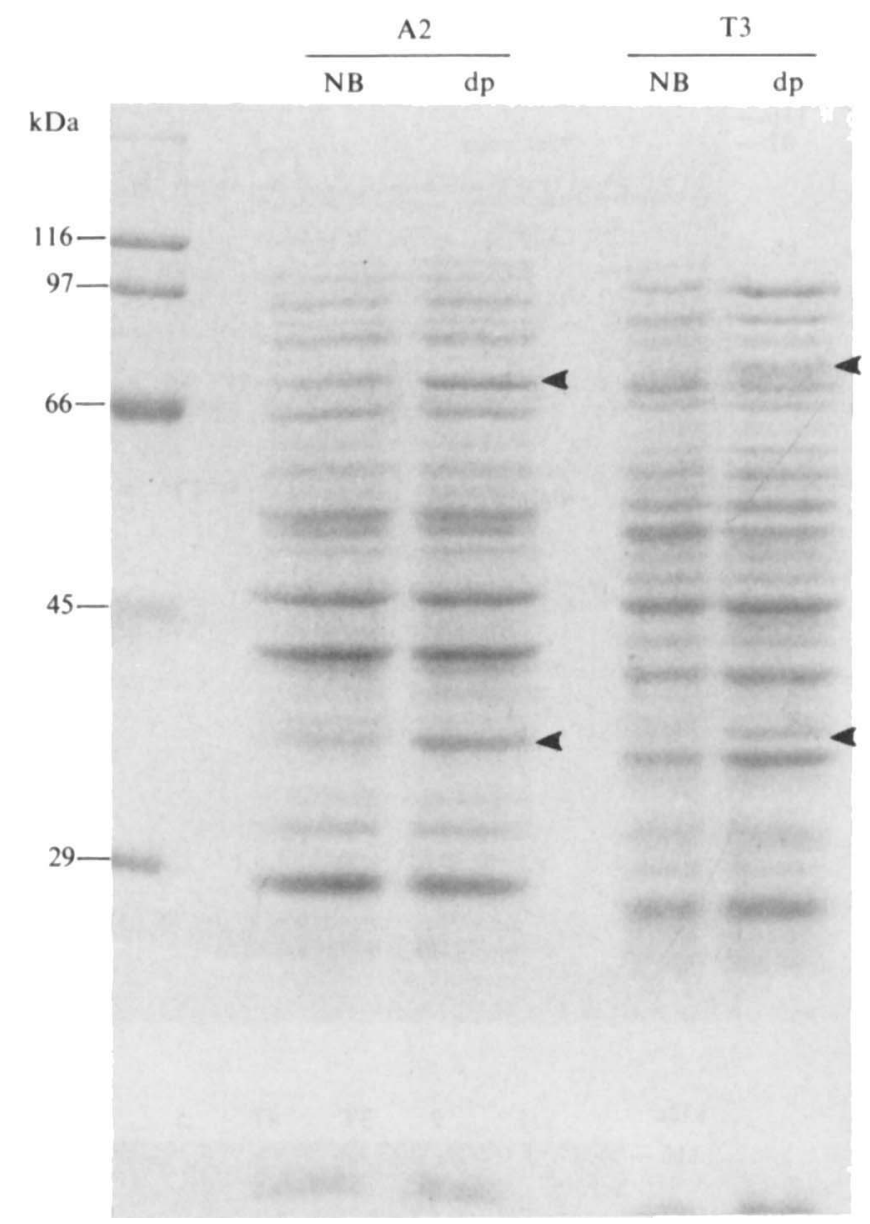

Fig. 1. SDS-PAGE of $P$, haemolytica A2 and T3 whole-cell proteins stained with Coomassie blue, showing the response to iron limitation. Arrowheads indicate A2 serotype 35 and $70 \mathrm{kDa}$ IRPs, and T3 serotype 37 and $78 \mathrm{kDa}$ IRPs.

Table 2. Reactivities of eight untypable isolates of $P$. haemolytica with polyclonal and monoclonal antibodies

A positive reaction with a monoclonal $(\mathrm{mAb})$ or polyclonal antibody $(\mathrm{pAb})$ is indicated by + .

\begin{tabular}{ccccc}
\hline \multicolumn{5}{c}{ Antibody specificity } \\
\cline { 2 - 5 } $\begin{array}{c}\text { Strain } \\
\text { no. }\end{array}$ & $\begin{array}{c}\text { Anti-35 kDa } \\
\text { mAb }\end{array}$ & $\begin{array}{c}\text { Anti-35 kDa } \\
\text { pAb }\end{array}$ & $\begin{array}{c}\text { Anti-70 kDa } \\
\text { pAb }\end{array}$ & $\begin{array}{c}\text { Proposed } \\
\text { biotype }\end{array}$ \\
\hline 1 & - & + & - & T \\
2 & + & + & - & $?$ \\
3 & - & + & + & $?$ \\
4 & + & + & + & A \\
5 & - & + & - & T \\
6 & - & + & + & $?$ \\
7 & + & + & + & A \\
8 & - & + & - & T \\
\hline \hline
\end{tabular}




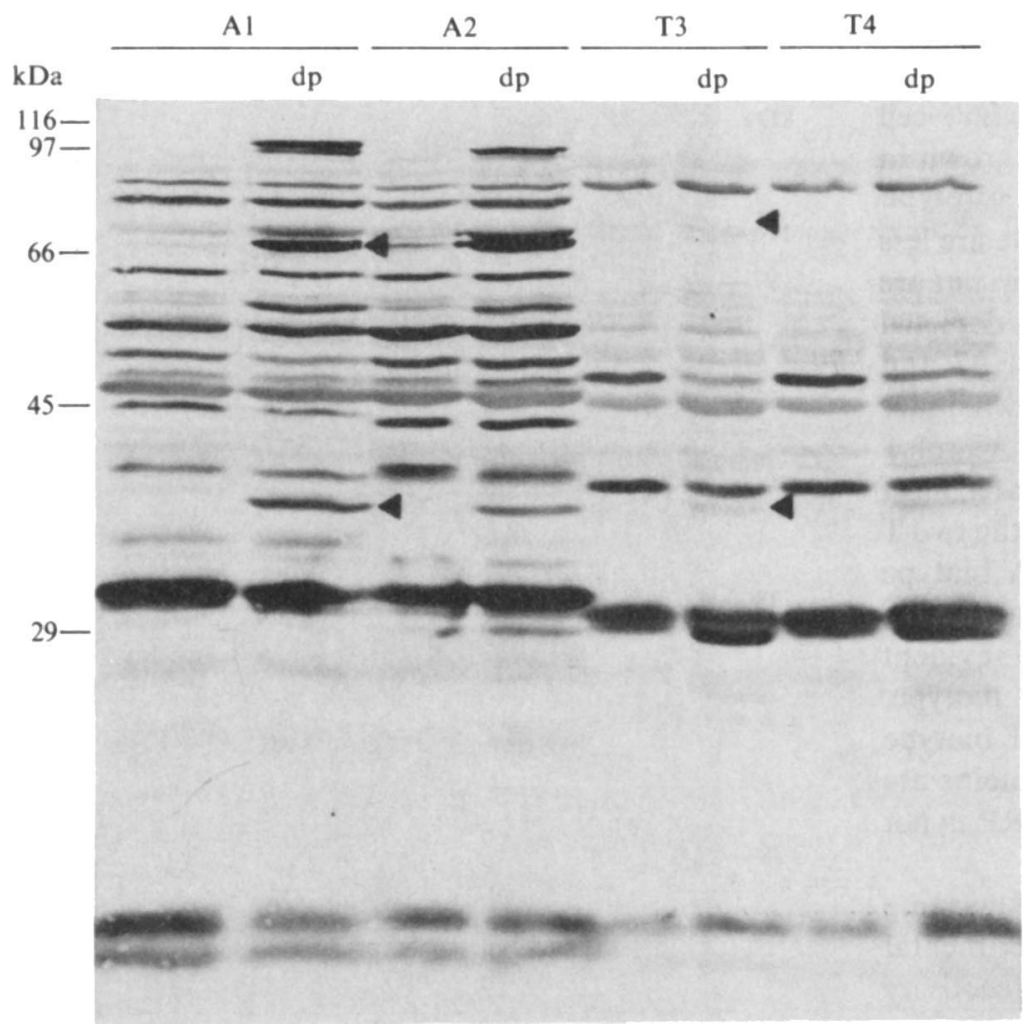

Fig. 2. Immunoblot of $P$. haemolytica whole cells, serotypes 1-4, grown in iron-replete and irondepleted conditions $(\mathrm{dp})$ reacted with pooled sera taken from lambs recovered from $P$. haemolytica A2 infection. Arrowheads indicate A1 serotype 35 and $70 \mathrm{kDa}$ IRPs, and T3 serotype 37 and $78 \mathrm{kDa}$ IRPs.

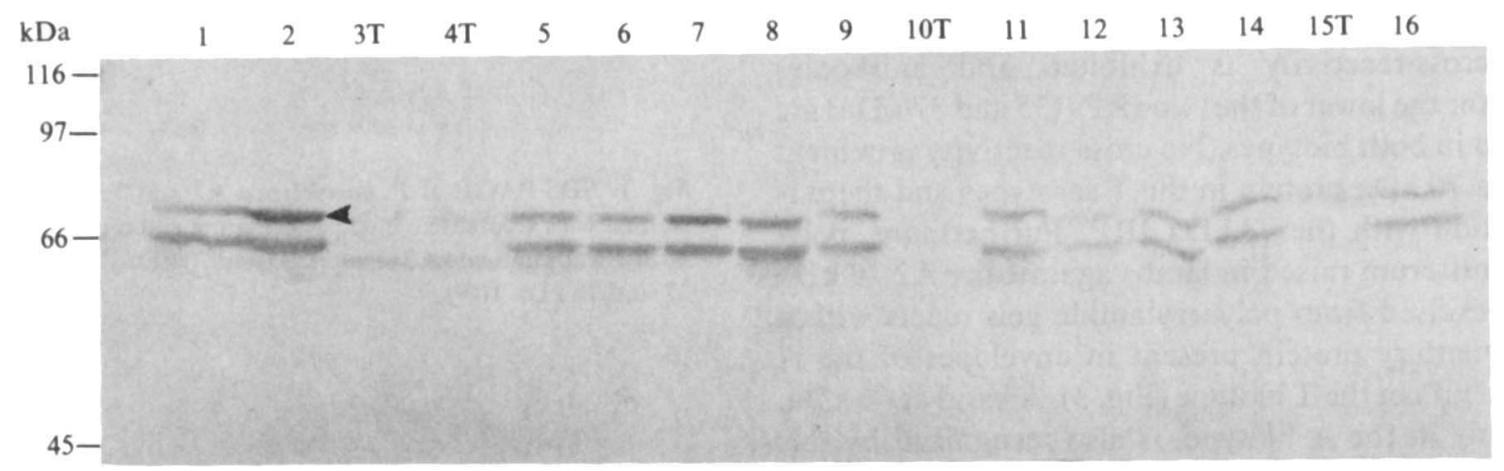

Fig. 3. Immunoblot of envelope preparations of $P$. haemolytica serotypes 1-16 grown under conditions of iron-limitation, reacted with sheep polyclonal antiserum raised against the A2 $70 \mathrm{kDa}$ IRP excised from polyacrylamide gels. The arrowhead indicates the $70 \mathrm{kDa}$ protein.

reactions with the two proteins in all eleven strains. Reactions were comparable with the standard A2 strain (Figs $5 a$ and $b$ ).

Whole-cell proteins from eight untypable $P$. haemolytica strains were separated by PAGE and examined in immunoblotting using the monoclonal antibodies and polyclonal antisera to the $35 \mathrm{kDa}$ IRP and also with polyclonal anti-70 $\mathrm{kDa}$ antiserum to identify crossreacting proteins (Table 2 ).

Five of the eight untypable strains examined gave reactivities identical to either the $A$ or the $T$ biotype. The remaining three strains could not be placed in either biotype on the basis of these reactivities. Strain 2, for example, had a protein that reacted with the $35 \mathrm{kDa}$ monoclonal antibody but lacked a protein which reacted with the anti-70 $\mathrm{kDa}$ polyclonal antiserum.

\section{Discussion}

To assess the degree of conservation of antigenic epitopes in and between the serotypes of $P$. haemolytica, immunoblotting with specific antibody was performed. The observations demonstrate that inter-serotype crossreactivity exists against both the 35 and $70 \mathrm{kDa}$ IRPs within the A biotype. Although the polyclonal anti$35 \mathrm{kDa}$ (A2) specific antiserum reacts with a $\mathrm{T}$ biotype 


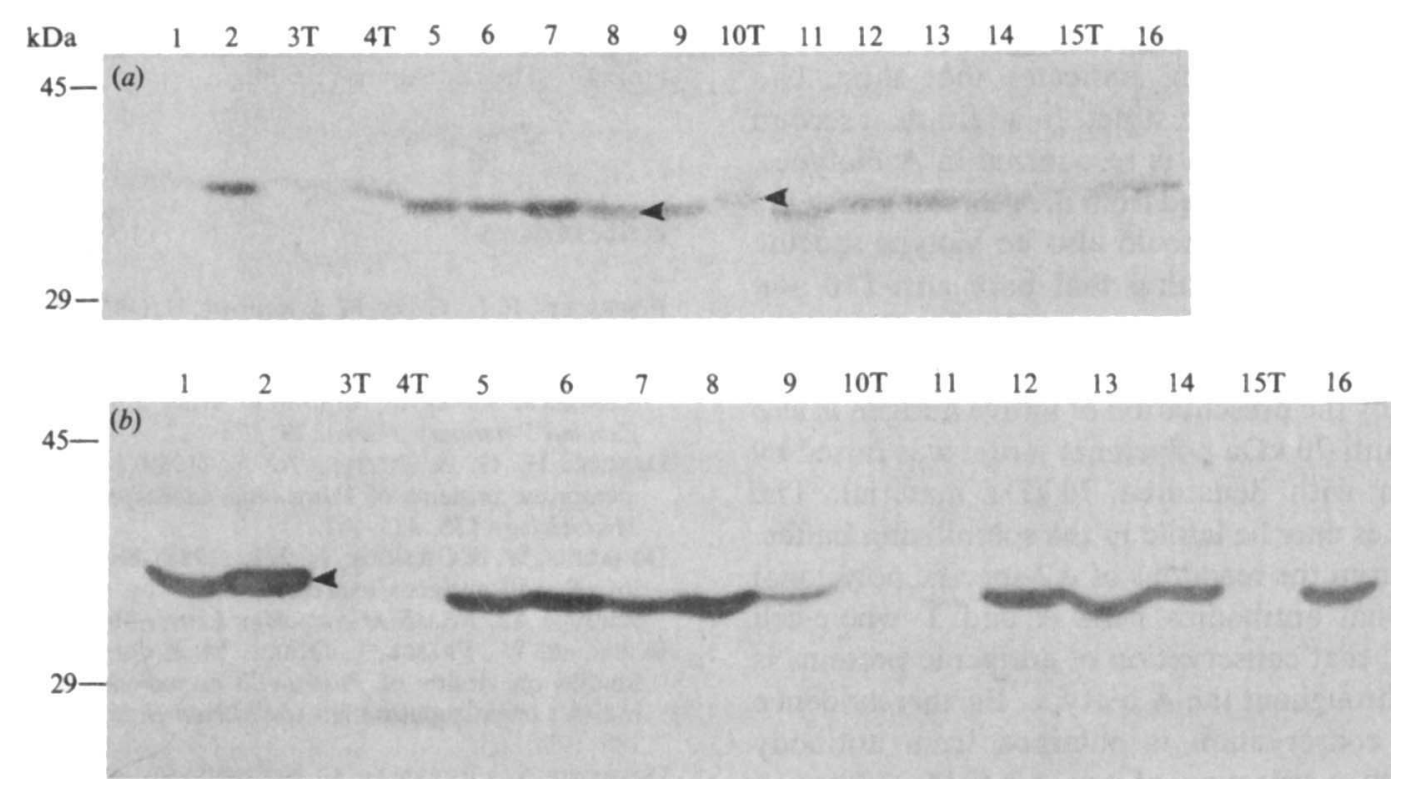

Fig. 4. (a) Immunoblot of $P$. haemolytica whole cells, serotypes 1-16, grown under conditions of iron-limitation reacted with polyclonal anti-35 kDa (A2) antiserum. For comparison, arrowheads indicate A8 serotype $35 \mathrm{kDa}$ protein and T10 serotype $37 \mathrm{kDa}$ protein. (b) Similar immunoblot reacted with culture supernatant from anti-35 kDa (A2) monoclonal cell line (12/16-6-11). The arrowhead indicates the $35 \mathrm{kDa}$ protein.

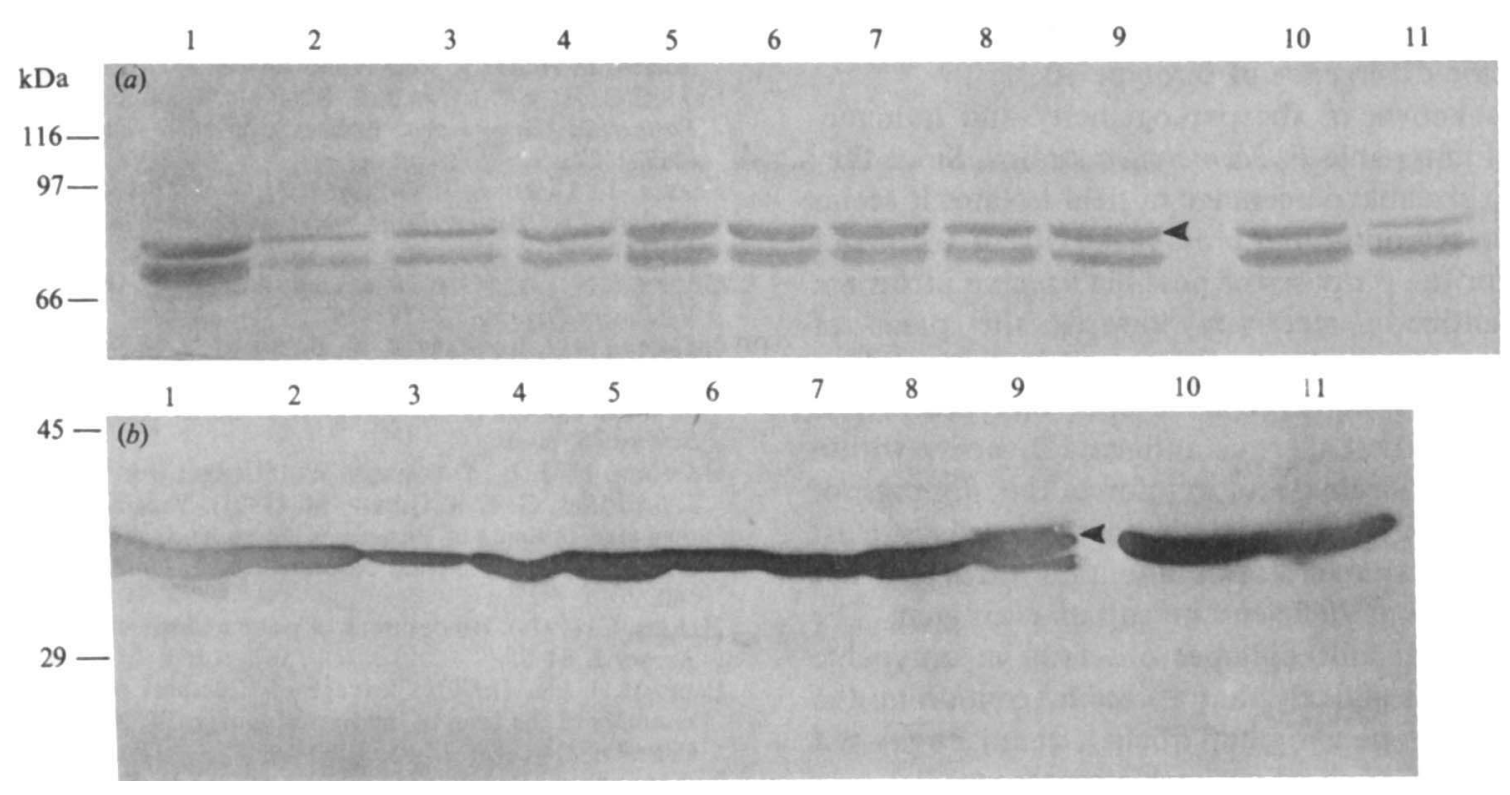

Fig. 5. (a) Immunoblot of A2 field isolate envelope proteins reacted with sheep polyclonal antiserum raised against the A2 (A713) $70 \mathrm{kDa}$ IRP excised from polyacrylamide gels. Lanes: 1, standard A2 strain; 2-11, strains Y578-D0203 as shown in Table 1. The arrowhead indicates the $70 \mathrm{kDa}$ protein. (b) Immunoblot of A2 field isolate whole-cell proteins reacted with culture supernatant from anti-35 kDa (A2, A713) monoclonal cell line (12/16-6-11). Lanes are as in (a). The arrowhead indicates the $35 \mathrm{kDa}$ protein.

protein, the lack of reactivity of the specific anti-35-kDa (A2) monoclonal antibody indicates that the $T$ biotype protein, although sharing common epitopes, is not identical. Mosier et al. (1989), have correlated the presence of serum antibodies to a $35 \mathrm{kDa}$ antigen with resistance to experimental $\mathrm{Al}$ challenge. It is not known whether this antigen is the same as the $35 \mathrm{kDa}$ antigen described here. The weak reactivity of serotype A11
$35 \mathrm{kDa}$ antigen compared to other A serotypes with the monoclonal antibody indicates that A11 differs from other A serotypes. Strains of this serotype have previously been shown to be different from other $A$ serotypes in such characteristics as production. of neuraminidase and sialoglycoprotease (Frank \& Tabatabai, 1981; Otulakowski et al., 1983).

The reactivity of the anti-70 $\mathrm{kDa}$ (A2) polyclonal 
antiserum with the $70 \mathrm{kDa} A$ biotype protein, but not the $78 \mathrm{kDa} \mathrm{T}$ biotype protein, indicates that these two proteins are antigenically distinct. In addition, a second non-iron-regulated antigen is recognized in A biotypes. Presumably, this was excised from the gels along with the $70 \mathrm{kDa}$ protein. Why it should also be biotype-specific is intriguing. It is interesting that both anti-T10 and anti-A2 convalescent sera react with the $T$ biotype $78 \mathrm{kDa}$ protein (unpublished observations). This could be explained by the presentation of native antigen in vivo whereas the anti-70 $\mathrm{kDa}$ polyclonal serum was raised by immunization with denatured $70 \mathrm{kDa}$ material. The shared epitopes may be labile in the solubilizing buffer.

It is clear from the reactions of A2-specific polyclonal and monoclonal antibodies with $\mathrm{A}$ and $\mathrm{T}$ whole-cell immunoblots, that conservation of antigenic proteins is maintained throughout the A biotype. Further evidence of antigenic conservation is obtained from antibody reactivity with a selection of ten A2 field isolates in which no variation was observed.

Deneer \& Potter (1989) showed antigenic crossreactivity between the IRPs of serotypes 1-12 using A1 convalescent calf serum. Although unable to show the IRPs as being biotype-dependent, they did speculate on the antigenic divergence of serotype 10 .

Little is known of the pathogenicity and immunogenicity of untypable $P$. haemolytica strains. Since they make up a sizeable percentage of field isolates it seems prudent to determine the cross-reactivity of the major antigens for the purposes of possible vaccine inclusion. Specific antibody reactivity towards the panel of untypable strains indicates that several strains show characteristics of either one or both biotypes. These results indicate that there is antigenic diversity within the untypable strains and reinforce the findings of Donachie et al. (1984) that distinct serogroups exist among the untypable strains and that these are not merely serogroups deficient in capsular antigen. The diversity of antigenic epitopes observed in untypable strains makes it unlikely that a vaccine containing the antigens of only one serogroup would immunize against a significant proportion of untypable serogroups.

Our results suggest that two IRPs with apparent molecular masses of 35 and $70 \mathrm{kDa}$ are conserved within the A biotype of $P$. haemolytica. The observed crossreactivity of polyclonal and monoclonal antibodies to the IRPs by immunoblotting suggests firstly that crossprotective immunity could occur within the A biotype and, therefore, for vaccine purposes the antigens expressed by a single A biotype strain may be sufficient to confer protection against $\mathrm{A}$ biotype infection. Secondly, these findings give further evidence that the A and $T$ biotypes of $P$. haemolytica may represent different species.
The authors wish to acknowledge the financial support given to this project by Hoechst Animal Yealth.

\section{References}

Biberstein, E. L., Gills, M. \& KNIGHT, H. (1960). Serological types of Pasteurella haemolytica. Cornell Veterinarian 50, 283-300.

Davies, D. H., Davis, G. B. \& Price, M. L. (1980). A longitudinal serological survey of respiratory virus infections in lambs. New Zealand Veterinary Journal 28, 125-127.

DENEER, H. G. \& PoTteR, A. A. (1989). Iron-repressible outermembrane proteins of Pasteurella haemolytica. Journal of General Microbiology 135, 435-443.

DONACHIE, W. \& GILMOUR, N. J. L. (1988). Sheep antibody responses to cell wall antigens expressed in vivo by Pasteurella haemolytica serotype A2. FEMS Microbiology Letters 56, 271-276.

Donachie, W., Fraser, J., Quirie, M. \& Gilmour, N. J. L. (1984). Studies on strains of Pasteurella haemolytica not typable by the indirect haemagglutination test. Research in Veterinary Science 37, 188-193.

Donachie, W., Burrells, C., Sutherland, A. D., Gilmour, J. S. \& GILMOUR, N. J. L. (1986). Immunity of specific pathogen-free lambs to challenge with an aerosol of Pasteurella haemolytica biotype A serotype 2 . Pulmonary antibody and cell responses to primary and secondary infections. Veterinary Immunology and Immunopathology 11, 265-279.

Fodor, L., VarGa, J., HaJtos, J., Donachie, W. \& Gilmour, N. J. L. (1988). Characterization of a new serotype of Pasteurella haemolytica isolated in Hungary. Research in Veterinary Science 44, 399.

Frank, G. H. \& Tabatabal, L. B. (1981). Neuraminidase activity of Pasteurella haemolytica isolates. Infection and Immunity $\mathbf{4 2}$, 1119-1122.

Fraser, J., Laird, S. \& Gilmour, N. J. L. (1982). A new serotype (biotype T) of Pasteurella haemolytica. Research in Veterinary Science 32, 127-128.

GiLmour, N. J. L. (1980). Pasteurella haemolytica infections in sheep. Veterinary Quarterly 2, 191-197.

Gilmour, N. J. L., Martin, W. B., Sharp, J. M., Thompson, D. A., Wells, P. W. \& DonaCHIE, W. (1983). Experimental immunization of lambs against pneumonic pasteurellosis. Research in Veterinary Science 35, 80-86.

Gilmour, N. J. L., Donachie, W., Sutherland, A. D., Gilmour, J. S., JoNES, G. E. \& QUIRIE, M. (1991). Vaccine containing ironregulated proteins of Pasteurella haemolytica A2 enhances protection against experimental pasteurellosis in lambs. Vaccine 9, 137140.

HARRIS, G. (1974). An outbreak of pasteurellosis in lambs. Veterinary Record 2, 84-85.

LAEMMLI, U. K. (1970). Cleavage of structural proteins during the assembly of the head of the bacteriophage T4. Nature, London 227, 680-685.

lainson, F. A., Harkins, D. C., Wilson, C. F., Sutherland, A. D., MurRaY, J. E., DONACHIE, W. \& BaIRD, G. D. (1991). Identification and localization of an iron-regulated $35 \mathrm{kDa}$ protein of Pasteurella haemolytica serotype A2. Journal of General Microbiology 137, 219-226.

Mosier, D. A., Simons, K. R., Confer, A. W., Panciera, R. J. \& Clinkenbeard, K. D. (1989). Pasteurella haemolytica antigens associated with resistance to pneumonic pasteurellosis. Infection and Immunity 57, 711-716.

Otulakowski, G. L., Shewen, P. E., Udoh, A. E., Mellors, A. \& WILKIE, B. N. (1983). Proteolysis of sialoglycoprotein by Pasteurella haemolytica cytotoxic culture supernatants. Infection and Immunity 42, 64-70.

ShARP, J. M. \& HeRring, A. J. (1983). Sheep pulmonary adenomatosis demonstration of a protein which cross-reacts with the major core proteins of Mason-Pfizer monkey virus and mouse mammary tumour virus. Journal of General Virology 64, 2323-2327. 